\title{
A methodology for the design of flexible renewable-based utility plants
}

\section{Supporting Information}

Salvador I. Pérez-Uresti ${ }^{a}$, Mariano Martín ${ }^{b *}$, Arturo Jiménez-Gutiérrez ${ }^{a}$

a Departamento de Ingeniería Química, Instituto Tecnológico de Celaya, Antonio García Cubas 600,Celaya, Gto. 38010, México

${ }^{b}$ Department of Chemical Engineering. University of Salamanca. Plz. Caidos 1-5, 37008, Spain

*Author for correspondence: Mariano Martín

Email: mariano.m3@usal.es

Phone: +34-923-294-479. Fax: +34-923-294-574

\section{List of Tables}

Table S1. Definition of sub-problems, SP-1

Table S2. Value of parameters for gasification and Reforming stages

Table S3. Value of $\mathrm{R}_{\mathrm{D}_{q}}^{\mathrm{n}, \mathrm{s}}$

Table S4. Value of parameters for syngas turbine

Table S5. Value of $\mathrm{R}_{\mathrm{q}, \mathrm{j}, \mathrm{k}}^{\mathrm{n}, \mathrm{f}}$ for syngas HRSG, system

Table S7. Value of parameters for biogas turbine

Table S8. Value of $\mathrm{R}_{\mathrm{q}, \mathrm{j}, \mathrm{K}}^{\mathrm{n}, \mathrm{f}}$ for biogas HRSG, system

Table S9. Constants of linearized cost functions

Table S10. Constants for linear piecewise cost function

Table S11. Monthly availability of renewable resource in Istmo de Tehuantepec, Mexico

Table S12. Conditions for the worst-case scenario

\section{List of Figures}

Figure S1. Conditions for Mexico case study a) weekly variations of solar radiation ${ }^{6}$, b) weekly variations of wind velocity $\left.{ }^{6}, \mathrm{c}\right)$ monthly profile of electricity demand ${ }^{7}, \mathrm{~d}$ ) weekly profile of electricity demand 


\section{S1. Modelling description}

In this section we provide a description of the model, and the main assumptions taken.

\section{S1.1.1 Biomass processing}

Selection of technologies to process biomass: The biomass that is used to produce utilities $(B)$ can be processed by selecting at most one technology, a biomass boiler $\left(B_{c}\right)$ or a gasifier reactor $\left(B_{q}\right)$. Equation (2) is a big-M constraint used to limit the use of biomass.

$$
\begin{gathered}
B=\sum_{q \in Q} B_{q}+B_{c} \\
B \leq B_{M A X} y_{\text {biomass }}
\end{gathered}
$$

Equation (3) indicates that the selection of any technology is conditioned to the selection of biomass. Equation (4) indicates the possible technologies to process biomass, while Equations (5)-(6) are constraints used to restrict the flowrate of biomass processed by each technology.

$$
\begin{gathered}
y_{\text {biomass }}-\left(\sum_{q \in Q} y_{q}+y_{c}\right)=0 \\
\sum_{q \in Q} y_{q}+y_{c} \leq 1 \\
B_{q} \leq B_{M A X} y_{q} \\
B_{c} \leq B_{M A X} y_{c}
\end{gathered}
$$

Biomass boiler: If a biomass boiler is selected, then it could generate as many as four types of steam, s, and it could carry out the steam reheating as well. This fact is modeled by Equations (7)-(10).

$$
\begin{aligned}
& y_{c}-\sum_{s \in S} y_{c}^{s} \leq 0 \\
& y_{c}-\sum_{\text {reheat_n } \in \text { REHEAT }} y_{\text {reheat_n } n}^{\text {s. }} \leq 0 \\
& \sum_{s \in S} y_{c}^{s} \geq 0 \\
& \sum_{\text {reheat_n } \in \text { REHEAT }} y_{\text {reheat_n }}^{s, C} \geq 0
\end{aligned}
$$

where production or non-production of steam, s, by biomass boiler, c, is represented by the binary variable $y_{c}^{S}$, while the variable $y_{\text {reheat_n }}^{s, C}$ is used to select the steam reheating, reheat_n . Steam production and reheating are restricted by the existence of the biomass boiler, according to Equations (7) and (8). 
Flowrate of the steam, $\mathrm{s}$, produced in the biomass boiler, $\mathrm{F}_{\mathrm{c}}^{\mathrm{s}}$, is computed by Equations (11)-(12).

$$
\begin{gathered}
Q_{c}^{s}=F_{c}^{s}\left[H\left(T^{s}, P^{s}\right)-H\left(T_{v 1}, P_{v 1}\right)\right] \forall s \\
F_{c}^{s} \leq F_{M A X} y_{c}^{s} \quad \forall s
\end{gathered}
$$

The heat required for the steam reheating is calculated as follows:

$$
\begin{gathered}
Q_{\text {reheat }}^{C}=\sum_{\text {reheat_n }} \sum_{R E H E A T} Q_{\text {reheat_n }}^{C} \\
Q_{\text {reheat_n }}^{C}=F_{\text {reheat_n }}^{s, C} * \Delta H_{\text {reheat_n } n} \forall \text { reheat_n } \\
F_{\text {reheat_n }}^{s, C} \leq F_{M A X} Y_{\text {reheat }}^{s, C} \quad \forall \text { reheat_n } n
\end{gathered}
$$

where $F_{\text {reheat_n }}^{s, C}$ is the flowrate of steam to be reheated in the biomass boiler and $Q_{\text {reheat_n }}^{C}$ is the heat required to carry out the steam reheating, reheat_n, selected.

Finally, a total heat balance for a biomass boiler is determined by Equations (16) and (17).

$$
\begin{gathered}
Q_{T c}=\sum_{s \in S} Q_{c}^{s}+Q_{\text {reheat }}^{C} \\
Q_{T c}=B_{c} L H V_{c}
\end{gathered}
$$

where $\mathrm{LHV}_{\mathrm{c}}$ is the Lower Heating Value of Biomass, $Q_{\mathrm{c}}^{\mathrm{s}}$ is the heat required to produce steam, while $Q_{\text {reheat }}^{C}$ is the heat required to reheat steam.

\section{S1.1.2 Syngas processing modelling approach}

The gasification stage was modeled as a surrogate model which consists of four steps. a) determination of the syngas composition, which is obtained in each gasifier, b) simulation of the reforming stage in Aspen plus, c) simulation of the syngas turbine in Aspen plus, d) Development of an optimization sub-routine to design the HRSG system. The syngas composition data via Indirect gasification (IG) and Direct gasification (DG) were taken from (1) and (2), respectively, and they were used to simulate the reforming stage in Aspen Plus. In the following section, the main assumptions for the development of the surrogate model are shown.

Reforming stage: POX reactions (18)-(19) were simulated in Aspen Plus as an Rstoic reactor. It was considered that the oxygen is fed in stoichiometric proportions. The conversions were taken the same as the ones reported by (3).

$$
\mathrm{C}_{\mathrm{n}} \mathrm{H}_{\mathrm{m}}+\frac{\mathrm{n}}{2} \mathrm{O}_{2} \rightarrow \mathrm{nCO}+\frac{\mathrm{m}}{2} \mathrm{H}_{2}
$$




$$
\mathrm{NH}_{3} \rightarrow \frac{1}{2} \mathrm{~N}_{2}+\frac{3}{2} \mathrm{H}_{2}
$$

On the other hand, steam reforming (SR) was simulated as an RGibbs reactor in Aspen plus. Steam is fed to the reactor in stoichiometric proportions. Furthermore, the conversions reported in (3) were assumed. The reactor conditions were determined by carrying out a sensitivity analysis of conversion in reactor against pressure and temperature.

Gas Turbine: There is a trade-off between power produced and the turbine outlet temperature (TOT). The higher the power produced the lower the TOT. Additionally, the net power produced is directly related to the compression ratio. Therefore, in order to evaluate such effects, a sensitivity analysis of the turbine outlet temperature with respect to the compression ratio was carried out in Aspen plus. The next considerations were taken:

1. Syngas is compressed to 10, 20 and 50 bar (represented as units GT-10, GT-20, GT-50 in Figure S2).

2. The excess air fed to the combustion chamber must be such that the turbine inlet temperature does not exceed $1400^{\circ} \mathrm{C}$.

3. Combustion chamber is simulated as an Rstoic reactor. The combustion efficiency was considered to be $98 \%$.

It worth pointing out that, for the purposes of this work, knowing the value of TOT is important since it determines the capability of the exhausted gas to produce heat in the HRSG system.

Heat Recovery Steam Generator: In this work, the single-pressure or multi-pressure performance of the HRSG was determined by carrying out an optimization problem. In this sense, a set of sub-problems, SP-1 (see Table S1), is evaluated in order to compute the optimal value $\boldsymbol{\Delta} \mathrm{T}_{\text {pinch }}$ that minimizes the total annual cost of each HRSG. For each sub-problem, $\mathrm{n}$, it is assumed that as many as two types of steam, s, can be generated in a single HRSG unit. The kind of the steam generated depends on the turbine exhaust gas temperature calculated from simulations. For instance, because of its temperature, the exhaust gas from unit GT-10 can generate VHP while the exhausted gas from unit GT20 cannot generate it. The set of steams that each turbine exhausted gas can generate are shown in Table S1. The sub-problems SP-1 are optimized in Matlab by using fmincon function. Additionally, the followings assumptions were considered:

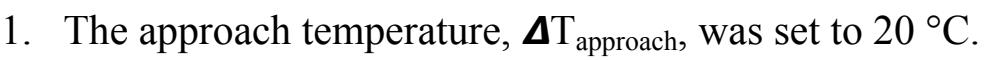

2. Operating cost of each steam were estimated by taking assumptions from (4).

3. To calculate the heat exchangers cost, the correlations proposed by (5) were used.

Table S1. Definition of sub-problems, SP-1

\begin{tabular}{|c|c|c|}
\hline $\begin{array}{c}\text { Type of } \\
\text { HRSG, } n\end{array}$ & Exhaust gas fed to HRSG & $\begin{array}{c}\text { Steam } \\
\text { generated }\end{array}$ \\
\hline
\end{tabular}




\begin{tabular}{|c|c|c|}
\hline $\mathbf{N}=\mathbf{1}$ & $\begin{array}{l}\text { GT-10/D } \mathrm{D}_{\mathrm{q}} \text { (Flue gas from combustor chamber at } \\
\qquad 995^{\circ} \mathrm{C} \text { ) }\end{array}$ & VHP \\
\hline 2 & $\mathrm{GT}-10 / \mathrm{D}_{\mathrm{q}}$ & $\mathrm{VHP}+\mathrm{HP}$ \\
\hline 3 & $\mathrm{GT}-10 / \mathrm{D}_{\mathrm{q}}$ & $\mathrm{VHP}+\mathrm{MP}$ \\
\hline 4 & GT-10/ D $/ \mathrm{GT}-20$ & HP \\
\hline 5 & GT-10/ D $/$ GT-20 & $\mathrm{HP}+\mathrm{MP}$ \\
\hline 6 & GT-10/ D ${ }_{q}$ GT-20/GT-50 & MP \\
\hline 7 & GT-10/ D $/$ GT-20/GT-50 & $\mathrm{MP}+\mathrm{LP}$ \\
\hline 8 & GT-20/GT-50 & LP \\
\hline
\end{tabular}

The sub-problem, SP-1, is represented by the set of Equations (20)-(29) and it consists of computing the optimal value of $\Delta \mathrm{T}_{\text {pinch, }}$, defined by Equation (27), that minimizes the total annual cost of each HRSG. Then, under the optimal conditions, the steam flowrate produced per unit per unit of exhausted gas fed to the HRSG, $\mathrm{R}_{\mathrm{q}, \mathrm{j}, \mathrm{k}}^{\mathrm{n}, \mathrm{s}}$, is computed. It worth pointing out that the sub-index of variables in equations, are referred for the HRSG flowsheet shown in Figure S2.

$$
\begin{aligned}
& \min _{x}\left\{\operatorname{TAC}^{\mathrm{n}}(x)\right\} \quad \forall \mathrm{n} \\
& \text { (SP-1) s.t. Eqs. } 20 \text { to } 29
\end{aligned}
$$

- Determining $\mathrm{R}_{\mathrm{q}, \mathrm{j}, \mathrm{k}}^{\mathrm{n}, \mathrm{s}}$ in HRSG, $\mathrm{n}$

$$
R_{q, j, k}^{n, S}=F_{m}^{n, s} / F_{m}^{n, g} \quad \forall n, s, q, j, k, m
$$

- Heat balance of steam $\mathrm{S}$ in Heat exchanger $\mathrm{m}$

$$
Q_{m}^{n, s}=F_{m}^{n, s}\left[H\left(T_{m}^{s}, P_{m}^{s}\right)-H\left(T_{m+1}^{s}, P_{m+1}^{s}\right)\right] \quad \forall m, s, n
$$

- Heat balance of steam exhaust gas, $\mathrm{G}_{\mathrm{q}, \mathrm{j}, \mathrm{k}}^{\mathrm{i}, \mathrm{n}}$, in Heat exchanger $\mathrm{m}$

$$
\begin{aligned}
T_{m=1}^{n, g}=\text { TOT }_{q, j, k} & \forall n, q, j, k \\
G_{q, j, k}^{n}=F_{m}^{n, g} & \forall n, q, j, k, m
\end{aligned}
$$




$$
\begin{gathered}
Q_{m}^{n, g}=F_{m}^{n, g} C_{p}\left(T_{m-1}^{n, g}-T_{m}^{n, g}\right) \quad \forall m, n \\
Q_{m}^{n, g}=Q_{m}^{n, s} \quad \forall m, s, n
\end{gathered}
$$

- Area of Heat exchanger m

$$
\mathrm{Q}_{\mathrm{m}}^{\mathrm{s}}=\mathrm{U}_{\mathrm{m}} \mathrm{A}_{\mathrm{m}} \Delta \mathrm{T}_{\mathrm{m}} \quad \forall \mathrm{m}, \mathrm{s}
$$

- Pinch temperature difference of HRSG $n$

$$
\Delta \mathrm{T}_{\mathrm{Pinch}}^{\mathrm{n}}=\mathrm{T}_{\mathrm{m}=2}^{\mathrm{n}, \mathrm{g}}-\mathrm{T}_{\mathrm{m}=2}^{\mathrm{s}} \forall \mathrm{n}
$$

- Cost of Heat exchanger $m$

$$
\mathrm{C}_{\mathrm{m}}=\mathrm{K}_{\mathrm{H}} \mathrm{A}_{\mathrm{m}}^{\alpha} \quad \forall \mathrm{m}
$$

-Total annualized cost of HRSG, n

$$
T A C^{n}=K_{F} \sum_{m \in \text { NHeat }} C_{m}-H_{y} \sum_{s \in S} 3600 *\left(F_{m}^{n, s} * C_{o p}^{s}\right) \quad \forall n
$$

In a second step, the data obtained from simulations and optimization sub-routines are used to formulate a set of disjunctions to select the optimal syngas processing route. Each disjunction is described in detailed below.

Gasification and reforming stage: When gasification is selected to process biomass, then, there are two options. Direct and indirect gasification. This fact is stated by Equation (30).

$$
\sum_{q \in Q} y_{q} \leq 1
$$

The requirements of steam and oxygen for the gasification stage are computed as follows:

$$
\begin{array}{cc}
S T_{q}=K_{S T_{q}} B_{q} & \forall q \\
O X_{q}=K_{O X_{q}} B_{q} & \forall q
\end{array}
$$


Flue gas from combustor chamber: Additional heat is recovered from IG process by feeding the leaving flue gas from combustor chamber at $995^{\circ} \mathrm{C}$ to a HRSG system. The flowrate of flue gas combustor chamber, $\mathrm{D}_{\mathrm{q}}$, is calculated using Equation (33).

$$
D_{q}=K_{D_{q}} B_{q} \quad \forall q
$$

where $\mathrm{K}_{\mathrm{D}_{\mathrm{q}}}$ is defined as ratio of $\mathrm{kg}$ of flue gas produced in combustor chamber per $\mathrm{kg}$ of biomass fed to gasifier reactor and its value is shown in Table S2. It is calculated by mass balances and taking assumptions shown in Phillips et al. (2007). It is worth pointing out that when direct gasification is selected, the value of $\mathrm{K}_{\mathrm{D}_{\mathrm{q}}}$ is zero.

The existence of the flue gas from the combustor chamber, $\mathrm{D}_{\mathrm{q}}$, is restricted to the selection of the gasification process (Equation 34). This flue gas is fed to a HRSG to produce one or two kinds of steam as Equations (35)-(37) state.

$$
\begin{gathered}
\sum_{q \in Q} y_{q}-\sum_{n \in N H R S G} y_{D q}^{n}=0 \\
\sum_{n \in N H R S G} y_{D q}^{n} \leq 1 \\
D_{q}=\sum_{n \in N H R S G} D_{q}^{n} \quad \forall q \\
D_{q}^{n} \leq D_{M A X} y_{D q}^{n} \forall q, n
\end{gathered}
$$

where $y_{D q}^{n}$ represents the selection of HRSG, $n$, which uses flue gas $D_{q}^{n}$ to produce steam and $\mathrm{D}_{\mathrm{MAX}}$ is the maximum capacity of the HRSG.

Equation (38) is used to calculate the flowrate of the steam generated in the HRSG, $\mathrm{F}_{D_{q}}^{\mathrm{n}, \mathrm{s}}$.

$$
F_{D_{q}}^{n, s}=R_{D_{q}}^{n, s} * D_{q}^{n} \quad \forall q, n, s
$$

where $R_{D_{q}}^{n, s}$ is defined as the ratio of $\mathrm{kg}$ of steam, s, generated in HRSG, n, per $\mathrm{kg}$ of the flue gas fed, $\mathrm{D}_{\mathrm{q}}^{\mathrm{n}}$, to HRSG and their values are shown in Table S3.

Reforming stage: To increase the hydrogen production, the syngas exiting from gasification stage is sent to the reformer reactor. The biomass flowrate that is processed via gasification, $\mathrm{q}$, and reforming, $\mathrm{j}$, is determined as follows:

$$
\begin{gathered}
B_{q}=\sum_{j \in J} B_{q, j} \forall q \\
\sum_{q \in Q} y_{q}-\sum_{q \in Q j \in J} \sum_{j, j} y_{y^{\prime}}=0
\end{gathered}
$$

where $\mathrm{y}_{\mathrm{q}, \mathrm{j}}$ is a binary variable used to represent the selection of the biomass processing via $q$ gasification and $\mathrm{j}$ reforming technologies. When binary variable $\mathrm{y}_{\mathrm{q}, \mathrm{j}}$ is equal to one, Equations (41)-(43) are activated 


$$
\begin{gathered}
\text { Water }_{q, j}=K_{W_{q, j}} B_{q, j} \forall q, j \\
\text { oxygen }_{q, j}=K_{O_{q j} j} B_{q, j} \forall q, j \\
S Y_{q, j}=K_{S Y_{q, j}} B_{q, j} \quad \forall q, j
\end{gathered}
$$

where parameters $\mathrm{K}_{\mathrm{OX}_{\mathrm{q}}}, \mathrm{K}_{\mathrm{ST}_{\mathrm{q}}}, \mathrm{K}_{\mathrm{W}_{\mathrm{q}, j}}, \mathrm{~K}_{\mathrm{O}_{\mathrm{q}, \mathrm{j}}}$ and $\mathrm{K}_{\mathrm{SY}_{\mathrm{q}, \mathrm{j}}}$ are calculated from simulations in Aspen plus and their values are shown in Table $\mathrm{S} 2$. Whereas $\mathrm{SY}_{\mathrm{q}, \mathrm{j}}$ is the syngas flowrate obtained by the gasification, $\mathrm{q}$, and the reforming $\mathrm{j}$.

\section{Options for syngas processing}

Once syngas is obtained, it can be sent to gas turbine, $\mathrm{SY}_{\mathrm{q}, \mathrm{j}, \mathrm{k}}$, or the syngas boiler $\mathrm{SY}_{\mathrm{q}, \mathrm{j}, \mathrm{sb}}$. This fact is stated by the following set of equations:

$$
\begin{gathered}
S Y_{q, j}=\sum_{k \in T U R B I N E} S Y_{q, j, k}+S Y_{q, j, s b} \forall q, j \\
S Y_{q, j, k} \leq S Y_{M A X} y_{q, j, k} \quad \forall q, j, k \\
S Y_{q, j, s b} \leq S Y_{M A X} y_{q, j, s b} \quad \forall q, j, s b \\
y_{q, j}-\left(\sum_{k \in T U R B I N E} y_{q, j, k}+y_{q, j, s b}\right)=0 \quad \forall q, j \\
\sum_{k \in T U R B I N E} y_{q, j, k}+y_{q, j, s b} \leq 1 \\
\sum_{k \in T U R B I N E} y_{q, j, k} \leq 1
\end{gathered}
$$

Equations (44) and (45) limit the flowrate of syngas that can be sent to the syngas boiler and syngas turbine, respectively. Whereas, $\mathrm{y}_{\mathrm{q}, \mathrm{j}, \mathrm{sb}}$ is the binary variable that indicates the selection or non-selection of the syngas boiler. In the same way, $\mathrm{y}_{\mathrm{q}, \mathrm{j}, \mathrm{k}}$ indicates the selection of gas turbine k. According to Equation (47), the selection of either gas turbine or syngas boiler is restricted by the type of gasification and reforming selected. In this way, the selection of at most one can be made (Equation 48). If the gas turbine is selected, then its selection is restricted to be at most one (Equation 49).

Syngas boiler: The flowrate of syngas that is sent to the boiler of syngas is represented by $\mathrm{SY}_{\mathrm{q}, \mathrm{j}, \mathrm{sb}}$. The boiler of syngas can generate as many as four kinds of steam and it can also carry out the reheating of the steam. This is represented by set of Equations (50)-(53) as follows: 


$$
\begin{gathered}
y_{q, j, s b}-\sum_{s \in S} y_{q, j, s b}^{s} \leq 0 \quad \forall q, j, s b \\
y_{q, j, s b}-\sum_{\text {reheat }_{n} \in R E H E A T} y_{\text {reheat }_{n}}^{s, q, j} \leq 0 \quad \forall q, j, s b \\
\sum_{s \in S} y_{q^{\prime}, j, s b}^{s,} \geq 0 \\
\sum_{\text {reheat }_{n} \in R E H E A T} y_{\text {reheat }_{n}}^{s, j, j} \geq 0 \quad \forall q, j
\end{gathered}
$$

where the binary variable, $\mathrm{y}_{\mathrm{q}, \mathrm{j}, \mathrm{sb}}^{\mathrm{s}}$, indicates the production of steam, s, by using syngas boiler, $s b$ while the variable $\mathrm{y}_{\text {reheat_n }}^{\mathrm{s}, \mathrm{n}, \mathrm{j}}$ is used to select the steam reheating, reheat_n, which is carried out by the syngas boiler which uses $\mathrm{SY}_{\mathrm{q}, \mathrm{j}, \mathrm{sb}}$. Note that either the steam production or reheating are restricted by the existence of the biomass boiler, according to Equation (50) and (51).

The flowrate of steam produced by the syngas boiler, $\mathrm{F}_{\mathrm{SB}_{\mathrm{q}, j}}^{\mathrm{S}}$, is calculated by using the following Equations

$$
\begin{gathered}
Q_{S B_{q, j}}^{S}=F_{S B_{q, j}}^{S}\left[H\left(T^{S}, P^{S}\right)-H\left(T_{v 1}, P_{v 1}\right)\right] \quad \forall q, j, s b, S \\
F_{S B_{q, j}}^{S} \leq F_{M A X} y_{q, j, s b}^{S} \forall q, j, s b
\end{gathered}
$$

The heat required for the steam reheating is calculated as follows:

$$
\begin{aligned}
& Q_{\text {reheat }}^{q, j}=\sum_{\text {reheat_n }} Q_{\text {REHEAT }}^{q, j} \text { iseat_n } \\
& Q_{\text {reheat_n }}^{q, j}=F_{\text {reheat } \_n}^{s, q, j} * \Delta H_{\text {reheat } \_n} \forall q, j, \text { reheat_n } \\
& F_{\text {reheat_n } n}^{s, q, j} \leq F_{M A X} y_{\text {reheat }}^{s, q, j} \forall q, j, \text { reheat_n }
\end{aligned}
$$

where $F_{\text {reheat_n }}^{s, q, j}$ is the flowrate of steam to be reheated in the syngas boiler which uses syngas, $S Y_{q, j, s b}$ and $Q_{r e h e a t}^{q} n_{n}$ is the heat required to carry out the steam reheating, reheat_n , selected.

Finally, the total heat in the syngas boiler is calculated by summing up the heat required to produce steam and steam reheating as Equation (59) sets. Furthermore, the flowrate of 
syngas, that is used in the syngas boiler, is calculated by the heat balance represented by Equation (60).

$$
\begin{aligned}
Q_{T S B_{q, j}} & =\sum_{S \in S} Q_{S B_{q, j}}^{S}+Q_{r e h e a t}^{q, j} \forall q, j \\
Q_{T S B_{q, j}} & =S Y_{q, j, s b} * L H V_{q, j} \forall q, j
\end{aligned}
$$

where $\mathrm{LHV}_{\mathrm{q}, \mathrm{j}}$ is the lower heating value of syngas, $S Y_{\mathrm{q}, \mathrm{j}}$ while $\mathrm{QS}_{\mathrm{S}}^{\mathrm{S}} \mathrm{B}_{\mathrm{j}}$ is the heat required to produce steam, $\mathrm{Q}_{\text {reheat }}^{\mathrm{j}} \mathrm{i}$ is the heat required to reheat .

Syngas Turbine: The syngas can be compressed to different pressures. Therefore, gas turbine, $\mathrm{k}$, is classified depending on its compression pressure. In this sense, when turbine $\mathrm{k}$ is selected, then the value of $\mathrm{y}_{\mathrm{q}, \mathrm{j}, \mathrm{k}}$ is one and the Equations (61)-(65) are activated.

$$
\begin{gathered}
A i r_{q, j, k}=K_{A_{q, j, k}} S Y_{q, j, k} \quad \forall q, j, k \\
P C o_{q, j, k}=\left(K_{S C o_{q, j, k}}+K_{A C o_{q, j, k}}\right) S Y_{q, j, k} \quad \forall q, j, k \\
P_{q, j, k}=K_{P_{q, j, k}} S Y_{q, j, k}-P C o_{q, j, k} \quad \forall q, j, k \\
G_{q, j, k}=K_{G_{q, j, k}} S Y_{q, j, k} \quad \forall q, j, k \\
C D_{q, j, k}=K_{C D_{q, j, k}} S Y_{q, j, k} \quad \forall q, j, k
\end{gathered}
$$

where $\mathrm{G}_{\mathrm{q}, \mathrm{j}, \mathrm{k}}$ is the flue gas produced in the turbine $\mathrm{k}$ due to the combustion of syngas $\mathrm{SY}_{\mathrm{q}, \mathrm{j}, \mathrm{k}}$ , while $\mathrm{K}_{\mathrm{P}_{\mathrm{q}, \mathrm{j}, \mathrm{k}}}, \mathrm{K}_{\mathrm{G}_{\mathrm{q}, \mathrm{j}, \mathrm{k}}}, \mathrm{K}_{\mathrm{CD}_{\mathrm{q} j \mathrm{j}, \mathrm{k}}}, \mathrm{K}_{\mathrm{A}_{\mathrm{q}, \mathrm{j}, \mathrm{k}}}, \mathrm{K}_{\mathrm{SCo}_{\mathrm{q} j \mathrm{j}, \mathrm{k}}}$ and $\mathrm{K}_{\mathrm{ACo}_{\mathrm{q}, \mathrm{j}, \mathrm{k}}}$ are parameters computed from simulations and their values are shown in Table $\mathrm{S} 4$.

HRSG: The flue gas produced in the gas turbine, $\mathrm{G}_{\mathrm{q}, \mathrm{j}, \mathrm{k}}$, is used to produce steam in an HRSG system. The possible HRSG configurations were stated according to the criteria explained above in Table S1 and they are limited by the existence of turbine $\mathrm{k}$ as follows:

$$
y_{q, j, k}-\sum_{n \in N H R S G} y_{q, j, k}^{n}=0 \forall q, j, k
$$

where $\mathrm{y}_{\mathrm{q}, \mathrm{j}, \mathrm{k}}^{\mathrm{n}}$ indicates the selection of configuration, $\mathrm{n}$, of HRSG which are restricted to be at most one as Equations (67) -(69) show:

$$
G_{q, j, k}=\sum_{n \in N H R S G} G_{q, j, k}^{n} \quad \forall q, j, k
$$




$$
\begin{array}{cc}
\sum_{n \in N H R S G} y_{q, j, k}^{n} \leq 1 & \forall q, j, k \\
G_{q, j, k}^{n} \leq G_{\max } y_{q, j, k}^{n} & \forall q, j, k, n
\end{array}
$$

where $G_{q, j, k}^{n}$ is the flowrate of exhaust gas that is sent to HRSG, n. Finally, the steam generated from HRSG, $\mathrm{n}$, is calculated as follows:

$$
F_{q, j, k}^{n, S}=G_{q, j, k}^{n} * R_{q, j, k}^{n, S} \quad \forall q, j, k, n, S
$$

where $\mathrm{R}_{\mathrm{q}, \mathrm{j}, \mathrm{k}}^{\mathrm{n}, \mathrm{k}}$ is computed by the optimization of SB-1 and it is defined as the ratio of $\mathrm{kg}$ of steam, $\mathrm{s}$, produced in HRSG, $\mathrm{n}$, per kg the exhaust gas, $\mathrm{G}_{\mathrm{q}, \mathrm{j}, \mathrm{k}}$. Their values are shown in Table S5.

Total production of biomass-based steam: total production of the biomass-based steam, $\mathrm{s}$, is calculated by the summation of the steam produced in the biomass boiler, $\mathrm{F}_{\mathrm{c}}^{\mathrm{s}}$, plus steam produced in the HRSG system, $\mathrm{F}_{\mathrm{q}, \mathrm{j}, \mathrm{k}}^{\mathrm{n}, \mathrm{s}}, \mathrm{F}_{\mathrm{D}_{\mathrm{q}}}^{\mathrm{n}, \mathrm{s}}$ and the syngas boiler, $\mathrm{F}_{\mathrm{SB}_{\mathrm{q}, j}}^{\mathrm{s}}$, as follows:

$$
F_{B}^{s}=\sum_{q \in Q} \sum_{j \in J} \sum_{k \in \text { Turbinen } \in N H R S G} \sum_{q, j, k, t}^{n, s}+F_{c_{t}}^{s}+\sum_{q \in Q j} \sum_{j \in} F_{S B_{q, j, t}}^{S}+\sum_{q \in Q} \sum_{n \in N H R S G} F_{D_{q, t}^{n, s}}^{n} \quad \forall s \in S
$$

Power produced in the syngas turbine: Power produced in the syngas turbine is calculated by Equation (72). It consists of the summation of the power produced by each syngas turbine, $\mathrm{k}, \mathrm{P}_{\mathrm{q}, \mathrm{j}, \mathrm{k}}$. In the same way, the total cooling required by the gas turbine is determined by Equation (73).

$$
\begin{gathered}
\text { Power }_{\text {biomass }}=\sum_{q \in Q j \in J} \sum_{k \in \text { Turbine }} P_{q, j, k} \\
C D_{\text {biomass }}=\sum_{q \in Q} \sum_{j \in j} \sum_{k \in \text { Turbine }} C D_{q, j, k}
\end{gathered}
$$

Table S2. Value of parameters for gasification and Reforming stages

\begin{tabular}{|c|c|c|c|c|c|c|c|}
\hline $\begin{array}{c}\text { Gasifier } \\
, \mathbf{q}=\end{array}$ & $\begin{array}{c}\text { Reforming } \\
, \mathbf{j}=\end{array}$ & $\mathbf{K}_{\mathbf{S T}_{\mathbf{q}}}$ & $\mathbf{K}_{\mathbf{\mathbf { O X } _ { \mathbf { q } }}}$ & $\mathbf{K}_{\mathbf{D}_{\mathbf{q}}}$ & $\mathbf{K}_{\mathbf{W}_{\mathbf{q}, \mathbf{j}}}$ & $\mathbf{K}_{\mathbf{O}_{\mathbf{q}} \mathbf{j}}$ & $\mathbf{K}_{\mathbf{S Y}_{\mathbf{q}, \mathbf{j}}}$ \\
\hline
\end{tabular}




\begin{tabular}{|c|c|c|c|c|c|c|c|}
\hline \multirow{2}{*}{ IG } & POX & 0.4 & 0 & $\begin{array}{c}2.7129896 \\
6\end{array}$ & 0 & 0.2024838 & 0.7408 \\
\cline { 2 - 8 } & SR & 0.4 & 0 & $\begin{array}{c}2.7129896 \\
6\end{array}$ & $\begin{array}{c}0.2977839 \\
3\end{array}$ & 0 & 0.5776 \\
\hline \multirow{2}{*}{ DG } & POX & 0.2 & 0.23 & 0 & 0 & $\begin{array}{c}0.3163026 \\
2\end{array}$ & $\begin{array}{c}0.2813761 \\
1\end{array}$ \\
\cline { 2 - 8 } & SR & 0.2 & 0.23 & 0 & $\begin{array}{c}0.2484359 \\
1\end{array}$ & 0 & $\begin{array}{c}0.3421405 \\
6\end{array}$ \\
\hline
\end{tabular}

Table S3. Value of $\mathrm{R}_{\mathrm{D}_{q}}^{\mathrm{n}, \mathrm{s}}$

\begin{tabular}{|c|c|c|c|c|}
\cline { 2 - 5 } \multicolumn{1}{c|}{} & \multicolumn{4}{c|}{$\mathbf{S}=$} \\
\cline { 2 - 5 } \multicolumn{1}{c|}{} & $\mathbf{V H P}$ & $\mathbf{H P}$ & MP & LP \\
\hline $\begin{array}{c}\text { HRSG, } \\
\mathbf{n}=\mathbf{1}\end{array}$ & 0.33896679 & 0 & 0 & 0 \\
\hline $\mathbf{2}$ & 0.24431734 & 0.0897417 & 0 & 0 \\
\hline $\mathbf{3}$ & 0.24619926 & 0 & 0.10664207 & 0 \\
\hline $\mathbf{4}$ & 0 & 0.38571956 & 0 & 0 \\
\hline $\mathbf{5}$ & 0 & 0.34136531 & 0.00140221 & 0 \\
\hline $\mathbf{6}$ & 0 & 0 & 0.41948339 & 0 \\
\hline $\mathbf{7}$ & 0 & 0 & 0.41354244 & 0.00199262 \\
\hline
\end{tabular}

Table S4. Value of parameters for syngas turbine

\begin{tabular}{|c|c|c|c|c|c|c|c|c|}
\hline $\begin{array}{c}\text { Turbine, } \\
\mathbf{k}=\end{array}$ & $\begin{array}{c}\text { Gasifier, } \\
\mathbf{q}=\end{array}$ & $\begin{array}{c}\text { Reforming, } \\
\mathbf{j}=\end{array}$ & $\mathbf{K}_{\mathbf{P}_{\mathbf{q}, \mathbf{j}, \mathbf{k}}}$ & $\mathbf{K}_{\mathbf{C D}_{\mathbf{q}, \mathbf{j}, \mathbf{k}}}$ & $\mathbf{K}_{\mathbf{G}_{\mathbf{q}, \mathbf{j}, \mathbf{k}}}$ & $\mathbf{K}_{\mathbf{A}_{\mathbf{q}, \mathbf{j}, \mathbf{k}}}$ & $\mathbf{K}_{\mathbf{A C o}_{\mathbf{q}, \mathbf{j}, \mathbf{k}}}$ & $\mathbf{K}_{\mathbf{S C o}_{\mathbf{q}, \mathbf{j}, \mathbf{k}}}$ \\
\hline \multirow{2}{*}{ GT-10 } & \multirow{2}{*}{ IG } & POX & 5301.83585 & 1480.76404 & 11.3687095 & 10.3671706 & 2944.92441 & 174.946004 \\
\cline { 3 - 9 } & \multirow{2}{*}{ DG } & SR & 7111.49584 & 1991.96676 & 14.9385388 & 13.9369806 & 3963.98892 & 249.307479 \\
\cline { 3 - 9 } & & SOX & 6328.55431 & 1766.51457 & 13.3677874 & 12.3828538 & 3505.62809 & 222.108408 \\
\hline \multirow{2}{*}{ GT-20 } & \multirow{2}{*}{ IG } & POX & 6078.55446 & 1707.42693 & 12.9541519 & 11.9545856 & 3388.08125 & 126.523546 \\
\cline { 3 - 9 } & & SR & 8017.72853 & 3734.61738 & 14.9385388 & 13.9369806 & 5048.47645 & 446.260388 \\
\hline
\end{tabular}




\begin{tabular}{|c|c|c|c|c|c|c|c|c|}
\hline \multirow{3}{*}{ DG } & POX & 7203.17013 & 3155.59838 & 13.3677874 & 12.3828538 & 4375.63799 & 409.41642 \\
\cline { 3 - 9 } & & SR & 6973.97593 & 3099.92482 & 12.9541519 & 11.9545856 & 4305.5989 & 227.275015 \\
\hline \multirow{3}{*}{ GT-50 } & \multirow{2}{*}{ IG } & POX & 6609.07127 & 3732.07343 & 11.3687095 & 10.3671706 & 5102.59179 & 194.384449 \\
\cline { 3 - 9 } & \multirow{2}{*}{ DG } & SR & 8709.55679 & 5092.72853 & 14.9385388 & 13.9369806 & 6936.98061 & 809.00277 \\
\cline { 3 - 8 } & & POX & 7855.67755 & 4523.69604 & 13.3677874 & 12.3828538 & 6141.2463 & 716.478734 \\
\cline { 3 - 8 } & & SR & 7575.83384 & 4372.09204 & 12.9541519 & 11.9545856 & 5934.40318 & 694.451436 \\
\hline
\end{tabular}

Table S5. Value of $\mathrm{R}_{\mathrm{q}, \mathrm{j}, \mathrm{k}}^{\mathrm{n}, \mathrm{s}}$ for syngas HRSG, system

\begin{tabular}{|c|c|c|c|c|c|c|c|}
\hline \multirow[b]{2}{*}{$\begin{array}{c}\text { Turbine, } \\
\mathbf{k}=\end{array}$} & \multirow[b]{2}{*}{$\begin{array}{c}\text { Gasifier, } \\
\mathbf{q}=\end{array}$} & \multirow[b]{2}{*}{$\begin{array}{c}\text { Reforming, } \\
\mathbf{j}=\end{array}$} & \multirow[b]{2}{*}{$\begin{array}{c}\text { HRSG, } \\
n=\end{array}$} & \multicolumn{4}{|c|}{$\mathbf{S}=$} \\
\hline & & & & VHP & HP & MP & $\mathbf{L P}$ \\
\hline \multirow{18}{*}{ GT-10 } & \multirow{14}{*}{ IG } & \multirow{7}{*}{ POX } & 1 & 0.220437 & 0 & 0 & 0 \\
\hline & & & 2 & 0.18573804 & 0.04232276 & 0 & 0 \\
\hline & & & 3 & 0.22033013 & 0 & 0.00168626 & 0 \\
\hline & & & 4 & 0 & 0.26256977 & 0 & 0 \\
\hline & & & 5 & 0 & 0.28553616 & 0.00073625 & 0 \\
\hline & & & 6 & 0 & 0 & 0.28906306 & 0 \\
\hline & & & 7 & 0 & 0 & 0.30465503 & 0.00483316 \\
\hline & & \multirow{7}{*}{ SR } & 1 & 0.2394438 & 0 & 0 & 0 \\
\hline & & & 2 & 0.22906141 & 0.00118192 & 0 & 0 \\
\hline & & & 3 & 0.23791425 & 0 & 0.00147161 & 0 \\
\hline & & & 4 & 0 & 0.28267671 & 0 & 0 \\
\hline & & & 5 & 0 & 0.26310545 & 0.00069525 & 0 \\
\hline & & & 6 & 0 & 0 & 0.31057937 & 0 \\
\hline & & & 7 & 0 & 0 & 0.32713789 & 0.0036153 \\
\hline & \multirow{4}{*}{ DG } & \multirow{4}{*}{ POX } & 1 & 0.25422872 & 0 & 0 & 0 \\
\hline & & & 2 & 0.18954787 & 0.06465426 & 0 & 0 \\
\hline & & & 3 & 0.23776596 & 0 & 0.00273936 & 0 \\
\hline & & & 4 & 0 & 0.29726064 & 0 & 0 \\
\hline
\end{tabular}




\begin{tabular}{|c|c|c|c|c|c|c|c|}
\hline & & & 5 & 0 & 0.26345745 & 0.00119681 & 0 \\
\hline & & & 6 & 0 & 0 & 0.32569149 & 0 \\
\hline & & & 7 & 0 & 0 & 0.32765957 & 0.00385638 \\
\hline & & \multirow{7}{*}{ SR } & 1 & 0.25959368 & 0 & 0 & 0 \\
\hline & & & 2 & 0.2369526 & 0.00180587 & 0 & 0 \\
\hline & & & 3 & 0.24598194 & 0 & 0.00232506 & 0 \\
\hline & & & 4 & 0 & 0.30404063 & 0 & 0 \\
\hline & & & 5 & 0 & 0.27232506 & 0.00106095 & 0 \\
\hline & & & 6 & 0 & 0 & 0.33329571 & 0 \\
\hline & & & 7 & 0 & 0 & 0.33860045 & 0.00388262 \\
\hline \multirow{20}{*}{ GT-20 } & \multirow{10}{*}{ IG } & \multirow{5}{*}{ POX } & 4 & 0 & 0.18982306 & 0 & 0 \\
\hline & & & 5 & 0 & 0.17736611 & 0.00085501 & 0 \\
\hline & & & 6 & 0 & 0 & 0.21178007 & 0 \\
\hline & & & 7 & 0 & 0 & 0.21155445 & 0.02910581 \\
\hline & & & 8 & 0 & 0 & 0 & 0.23157582 \\
\hline & & & 4 & 0 & 0.21275782 & 0 & 0 \\
\hline & & & 5 & 0 & 0.19928158 & 0.00082271 & 0 \\
\hline & & SR & 6 & 0 & 0 & 0.23652375 & 0 \\
\hline & & & 7 & 0 & 0 & 0.24003476 & 0.02560834 \\
\hline & & & 8 & 0 & 0 & 0 & 0.25644264 \\
\hline & & & 4 & 0 & 0.23417553 & 0 & 0 \\
\hline & & & 5 & 0 & 0.20635638 & 0.00135638 & 0 \\
\hline & & POX & 6 & 0 & 0 & 0.25885638 & 0 \\
\hline & & & 7 & 0 & 0 & 0.24848404 & 0.02507979 \\
\hline & $\mathrm{DC}$ & & 8 & 0 & 0 & 0 & 0.27925532 \\
\hline & & & 4 & 0 & 0.23322799 & 0 & 0 \\
\hline & & & 5 & 0 & 0.20819413 & 0.00124153 & 0 \\
\hline & & SR & 6 & 0 & 0 & 0.25844244 & 0 \\
\hline & & & 7 & 0 & 0 & 0.25022573 & 0.02702032 \\
\hline & & & 8 & 0 & 0 & 0 & 0.27837472 \\
\hline GT-50 & IG & POX & 6 & 0 & 0 & 0.14467403 & 0 \\
\hline
\end{tabular}




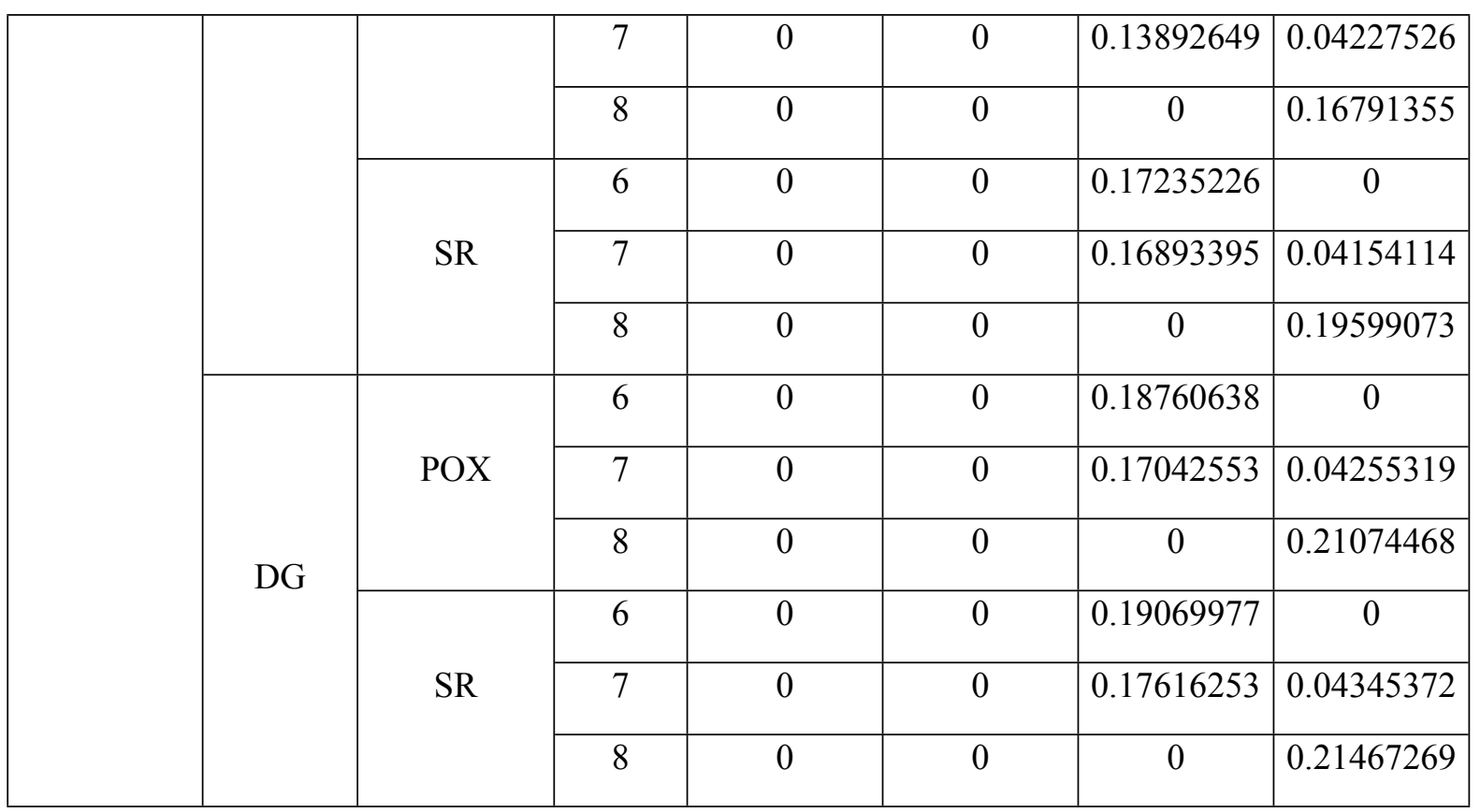

Table S6. Value of parameters for digestor

\begin{tabular}{|c|c|c|c|c|}
\hline $\mathbf{Z}=$ & $\mathbf{K}_{\mathbf{C H} 4}^{\mathbf{Z}}$ & $\mathbf{K}_{\mathbf{C 0 2}}^{\mathbf{Z}}$ & $\mathbf{K}_{\mathbf{W}}^{\mathbf{Z}}$ & $\mathbf{K}_{\text {Ammonia }}^{Z}$ \\
\hline $\mathrm{CM}$ & 0.008 & 0.0098 & 0.0025 & $1.1346 \mathrm{E}-06$ \\
\hline $\mathrm{MW}$ & 0.0387 & 0.0473 & 0.012 & $5.4811 \mathrm{E}-06$ \\
\hline
\end{tabular}

Table S7. Value of parameters for biogas turbine

\begin{tabular}{|c|c|c|c|c|c|c|}
\hline Turbine, $\mathrm{k}=$ & $\mathrm{K}_{\mathrm{p}_{\mathrm{k}}}^{\text {biogas }}$ & $\mathrm{K}_{A_{\mathrm{k}}}^{\text {biogas }}$ & $\mathrm{K}_{\mathrm{G}_{\mathrm{k}}}^{\text {biogas }}$ & $\mathrm{K}_{C D_{\mathrm{k}}}^{\text {biogas }}$ & $\mathrm{K}_{A C O_{\mathrm{k}}}^{\text {biogas }}$ & $\mathrm{K}_{S C \mathrm{O}_{\mathrm{k}}}^{\text {bigas }}$ \\
\hline GT-10 & 15007.50 & 32.5 & 33.62 & 4641.25 & 9243 & 184.5 \\
\hline GT-20 & 17302.50 & 32.5 & 33.62 & 8015 & 11610 & 337.5 \\
\hline GT-50 & 18810.00 & 32.5 & 33.62 & 11083.75 & 16200 & 540 \\
\hline
\end{tabular}

Table S8. Value of $\mathrm{R}_{\mathrm{q}, \mathrm{j}, \mathrm{k}}^{\mathrm{n}, \mathrm{f}}$ for biogas HRSG, system 


\begin{tabular}{|c|c|c|c|c|c|}
\hline Turbine, $\mathrm{k}=$ & HRSG, $n=$ & VHP & HP & MP & LP \\
\hline \multirow{7}{*}{ GT-10 } & 1 & 0.2471 & 0 & 0 & 0 \\
\hline & 2 & 0.1127 & 0.1525 & 0 & 0 \\
\hline & 3 & 0.1191 & 0 & 0.1651 & 0 \\
\hline & 4 & 0 & 0.2879 & 0 & 0 \\
\hline & 5 & 0 & 0.1376 & 0.1558 & 0 \\
\hline & 6 & 0 & 0 & 0.3152 & 0 \\
\hline & 7 & 0 & 0 & 0.2924 & 0.0152 \\
\hline \multirow{5}{*}{ GT-20 } & 4 & 0 & 0.2194 & 0 & 0 \\
\hline & 5 & 0 & 0.0786 & 0.1544 & 0 \\
\hline & 6 & 0 & 0 & 0.2433 & 0 \\
\hline & 7 & 0 & 0 & 0.2082 & 0.0387 \\
\hline & 8 & 0 & 0 & 0 & 0.262 \\
\hline \multirow{3}{*}{ GT-50 } & 6 & 0 & 0 & 0.1767 & 0 \\
\hline & 7 & 0 & 0 & 0.1408 & 0.0514 \\
\hline & 8 & 0 & 0 & 0 & 0.2009 \\
\hline
\end{tabular}

Table S9. Constants of linearized cost functions

\begin{tabular}{|c|c|}
\hline & (\$MM USD) \\
\hline $\mathrm{A}_{\mathrm{c}}$ & $2.37 \mathrm{E}-4$ \\
\hline $\mathrm{B}_{\mathrm{c}}$ & 2 \\
\hline $\mathrm{A}_{\mathrm{sb}}$ & $2.37 \mathrm{E}-4$ \\
\hline $\mathrm{B}_{\mathrm{sb}}$ & 2 \\
\hline $\mathrm{A}_{\mathrm{T}}$ & $3.18 \mathrm{E}-4$ \\
\hline $\mathrm{B}_{\mathrm{T}}$ & $4.028 \mathrm{E}-1$ \\
\hline $\mathrm{A}_{\mathrm{HRSG}}$ & 2 \\
\hline $\mathrm{B}_{\mathrm{HRSG}}$ & 6.636 \\
\hline
\end{tabular}




\begin{tabular}{|c|c|}
\hline $\mathrm{A}_{\text {gas }}$ & 2.2968 \\
\hline $\mathrm{B}_{\text {gas }}$ & 183.42 \\
\hline $\mathrm{A}_{\text {Opgas }}$ & 0.0622 \\
\hline $\mathrm{B}_{\text {Opgas }}$ & 0 \\
\hline $\mathrm{A}_{\text {COMP }}$ & $7.71 \mathrm{E}-4$ \\
\hline $\mathrm{B}_{\text {COMP }}$ & $1.74 \mathrm{E}-1$ \\
\hline $\mathrm{A}_{\text {Biogas }}$ & 0.4935 \\
\hline $\mathrm{B}_{\text {biogas }}$ & 28.301 \\
\hline $\mathrm{A}_{\text {Opbiogas }}$ & $3.7409 \mathrm{E}-6$ \\
\hline $\mathrm{B}_{\text {Opbiogas }}$ & $2.2929 \mathrm{E}-4$ \\
\hline $\mathrm{A}_{\text {BGB }}$ & $2.132 \mathrm{E}-3$ \\
\hline $\mathrm{B}_{\text {BGB }}$ & $1.0267 \mathrm{E}-2$ \\
\hline $\mathrm{A}_{\text {BiogasT }}$ & $1.018 \mathrm{E}-3$ \\
\hline $\mathrm{B}_{\text {BiogasT }}$ & $3.553 \mathrm{E}-3$ \\
\hline $\mathrm{A}_{\text {BiogasCOMP }}$ & $7.82 \mathrm{E}-4$ \\
\hline $\mathrm{B}_{\text {BiogasCOMP }}$ & $1.4656 \mathrm{E}-2$ \\
\hline $\mathrm{A}_{\text {BIO - HRSG }}$ & 9 \\
\hline $\mathrm{B}_{\text {BIO - HRSG }}$ & $1.5445 \mathrm{E}-2$ \\
\hline
\end{tabular}

Table S10. Constants for linear piecewise cost function

\begin{tabular}{|c|c|c|c|c|c|}
\hline $\mathbf{A}_{\text {cun }}=$ & $\mathbf{0}$ & $\mathbf{1}$ & $\mathbf{2 5}$ & $\mathbf{1 4 0}$ & $\mathbf{1 0 0 0}$ \\
\hline $\mathrm{B}_{\mathrm{CU}}(\$ M M U S D)$ & 0 & $2.94 \mathrm{E}-4$ & $1.499 \mathrm{E}-3$ & $1.593 \mathrm{E}-3$ & $3.94 \mathrm{E}-2$ \\
\hline $\mathrm{D}_{\mathrm{CU}}(\$ M M U S D)$ & 0 & $-1.5 \mathrm{E}-5$ & $-3.508 \mathrm{E}-3$ & $2.583 \mathrm{E}-3$ & $1.86 \mathrm{E}-1$ \\
\hline Power $_{\mathrm{ST}}=$ & $\mathbf{0}$ & $\mathbf{1}$ & $\mathbf{1 0}$ & $\mathbf{6 0}$ & $\mathbf{7 0 0}$ \\
\hline $\mathrm{B}_{\mathrm{ST}}(\$ M M U S D)$ & 0 & $5.03 \mathrm{e}-1$ & $1.02 \mathrm{E}-1$ & $3.22 \mathrm{E}-2$ & $1.56 \mathrm{E}-2$ \\
\hline $\mathrm{D}_{\mathrm{ST}}(\$ M M U S D)$ & 0 & $1.64 \mathrm{E}-1$ & $6.19 \mathrm{E}-1$ & 1 & 2 \\
\hline Qcooling & $\mathbf{0}$ & $\mathbf{1 0 0 0 0}$ & $\mathbf{1 5 0 0 0}$ & $\mathbf{2 5 0 0 0}$ & $\mathbf{5 0 0 0 0}$ \\
\hline
\end{tabular}




\begin{tabular}{|c|c|c|c|c|c|}
\hline $\mathrm{B}_{\mathrm{CT}}($ MMMUS $)$ & 0 & 0.74592 & 0.947 & 1.2818 & 1.9307 \\
\hline $\mathrm{D}_{\mathrm{CT}}($ MMMUSD $)$ & 0 & 0 & 0 & 0 & 0 \\
\hline
\end{tabular}

\section{S2. Figures and data for case studies}

\section{Mexico}

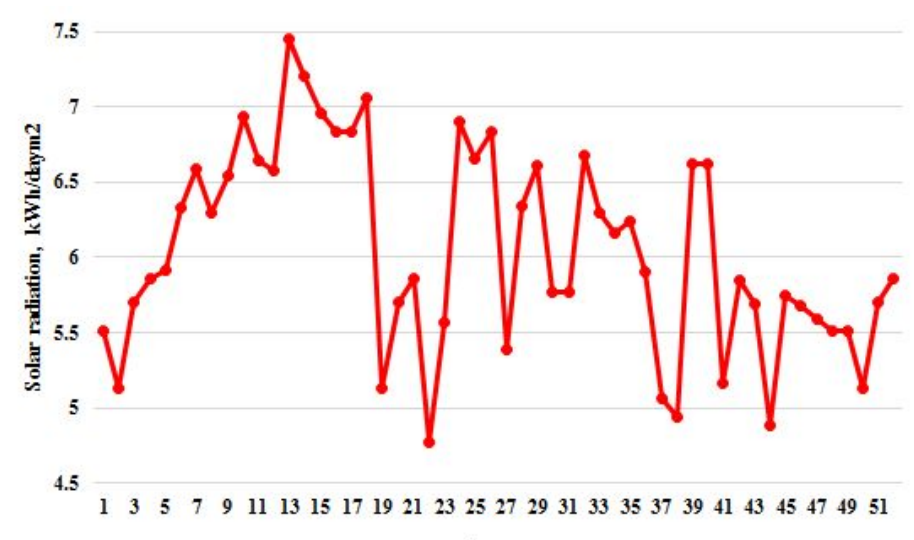

a)

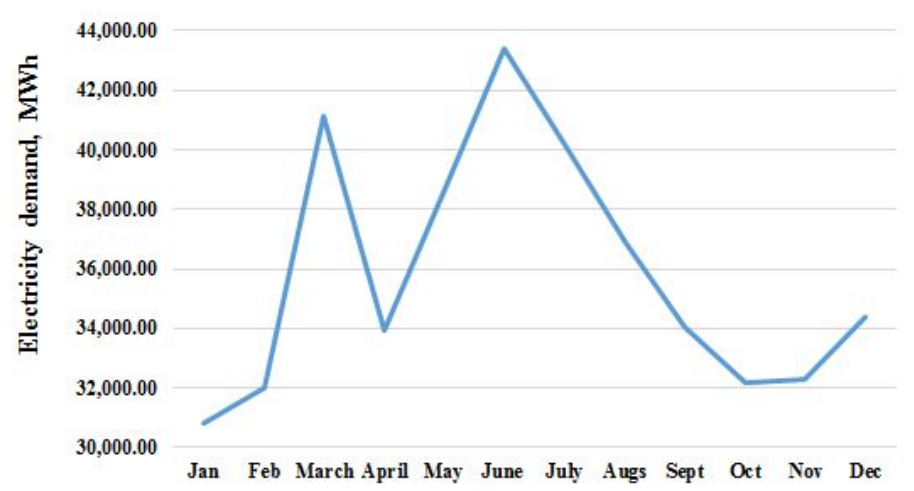

c)

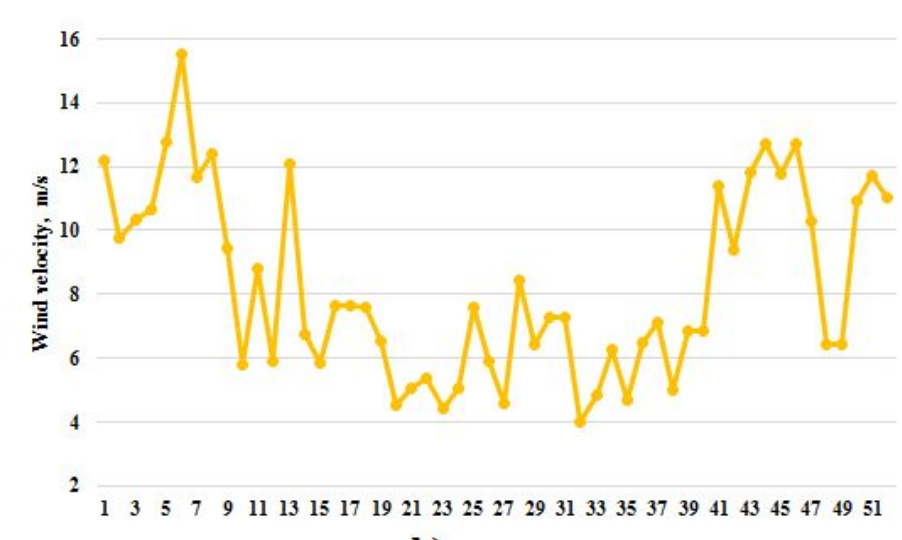

b)

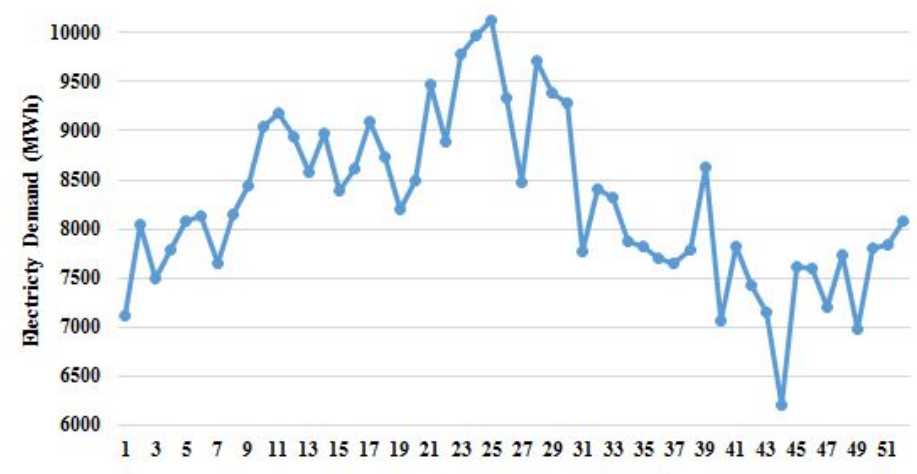

d)

Figure S1. Conditions for Mexico case study a) weekly variations of solar radiation ${ }^{6}$, b) weekly variations of wind velocity $^{6}$, c) monthly profile of electricity demand ${ }^{7}$, d) weekly profile of electricity demand ${ }^{7}$.

Table S11. Monthly availability of renewable resource in Istmo de Tehuantepec, Mexico $^{6-10}$

$\begin{array}{ccccc}\text { Solar } & \text { Wind } & \text { Biomass } & \text { Cattle } & \text { Municipal } \\ \text { radiation } & \text { velocity } & \begin{array}{c}\text { Manure } \\ \text { (ton/month) }\end{array} & \begin{array}{c}\text { solid waste } \\ (\text { ton } / \text { month })\end{array} & (\text { ton } / \text { month })\end{array}$




\begin{tabular}{cccccc}
\hline January & 5.56 & 11.75 & 5,705 & 62,940 & 5,280 \\
February & 6.22 & 11.75 & 5,153 & 56,850 & 4,766 \\
March & 6.81 & 11.75 & 5,705 & 62,940 & 5,280 \\
April & 7.08 & 9.75 & 5,520 & 60,910 & 5,106 \\
May & 6.68 & 8.75 & 5,705 & 62,940 & 5,280 \\
June & 5.99 & 7.75 & 5,520 & 60,910 & 5,106 \\
July & 6.36 & 7.75 & 5,705 & 62,940 & 5,280 \\
August & 6.19 & 7.75 & 5,705 & 62,940 & 5,280 \\
September & 5.53 & 7.75 & 5,520 & 60,910 & 5,106 \\
October & 5.61 & 9.75 & 5,705 & 62,940 & 5,280 \\
November & 5.50 & 11.75 & 5,520 & 60,910 & 5,106 \\
December & 5.50 & 11.5 & 5,705 & 62,940 & 5,280 \\
\hline Population: 330,381 & & & &
\end{tabular}

Population: 330, 381 inhabits; Cattle heads: 42,674

Table S12. Conditions for the worst-case scenario ${ }^{6-7}$.

\begin{tabular}{ll}
\hline \multicolumn{2}{c}{ June 8th, 2011 } \\
\hline Solar radiation ( $\mathbf{k W h} / \mathbf{m}^{\mathbf{2}}$ day) & 4.06 \\
Wind velocity (m/s) & 2.94 \\
Electricity demand (MWh/day) & 1474.80 \\
LP steam demand (kg/s) & 15.40 \\
\hline
\end{tabular}

\section{Nomenclature}

\section{Parameters}

$\mathrm{R}_{\mathrm{q}, \mathrm{j}, \mathrm{k}}^{\mathrm{i}, \mathrm{s}} \mathrm{kg}$ of steam, s, produced in HRSG, n, per kg of exhaust gas $\mathrm{G}_{\mathrm{q}, \mathrm{j}, \mathrm{k}}^{. \mathrm{n}}$

$\mathrm{A}_{c}$ : Constant of the linearized biomass boiler cost function

$\mathrm{A}_{\mathrm{COMP}}$ : Constant of the linearized compressor cost function

$\mathrm{A}_{\text {gas }}:$ Constant of the linearized gasification and reforming cost function

$\mathrm{A}_{\mathrm{HRSG}}$ : Constant of the linearized HRSG cost function

$\mathrm{A}_{\text {Opgas: }}$ : Constant of the linearized gasification and reforming operation cost function

$\mathrm{A}_{\mathrm{sb}}$ : Constant of the linearized syngas boiler cost function

$\mathrm{A}_{\mathrm{T}}$ : Constant of the linearized gas turbine cost function 
$\mathrm{B}_{\mathrm{BGB}}$ : Independent term of the linearized biogas boiler cost function

$\mathrm{B}_{\text {biogas: }}$ : Independent term of the linearized digestor and separation stage cost function

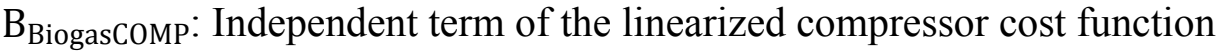

$\mathrm{B}_{\text {Biogas } \mathrm{T}}$ : Independent term of the linearized biogas turbine cost function

$\mathrm{B}_{\mathrm{BIO}}$ - HRSG: Independent term of the linearized HRSG cost function

$\mathrm{B}_{\mathrm{c}}$ : Independent term of the linearized biomass boiler cost function

$\mathrm{B}_{\mathrm{cMAX}}$ : Maximum biomass flowrate that biomass boiler can process $(\mathrm{kg} / \mathrm{s})$

$\mathrm{B}_{\mathrm{COMP}}$ : Independent term of the linearized compressor cost function

$\mathrm{B}_{\text {gas }}$ : Independent term of the linearized gasification and reforming cost function

$\mathrm{B}_{\mathrm{HRSG}}$ : Independent term of the linearized HRSG cost function

$\mathrm{B}_{\text {Opbiogas }}$ : Independent term of the linearized digestor and separation stage operation cost function

$\mathrm{B}_{\text {Opgas: }}$ : Independent term of the linearized gasification and reforming operation cost function

$\mathrm{B}_{\mathrm{qMAX}}$ : Maximum biomass flowrate that gasifier can process $(\mathrm{kg} / \mathrm{s})$

$\mathrm{B}_{\mathrm{sb}}$ : Independent term of the linearized syngas boiler cost function

$\mathrm{B}_{\mathrm{T}}$ : Independent term of the linearized gas turbine cost function

$\mathrm{C}_{\mathrm{bio}}:$ Biomass cost $(\$ / \mathrm{kg})$

$\mathrm{C}_{\text {Heliostat }}:$ Cost of heliostat $\left(\$ \mathrm{USD} / \mathrm{m}^{2}\right)$

$\mathrm{C}_{\text {Msalt }}:$ cost of molten salt ( $\left.\$ \mathrm{USD} / \mathrm{kg}\right)$

$\mathrm{C}_{\mathrm{Op}}^{\mathrm{CSP}}$ : Operating cost of CSP plat (\$USD $\left./ \mathrm{kWh}\right)$

$\mathrm{C}_{\mathrm{op}}^{\mathrm{s}}$ : Operation cost of steam, $\mathrm{s}(\$ \mathrm{USD} / \mathrm{s})$

$\mathrm{C}_{\text {psalt }}$ : Molten salt heat capacity $\left(\mathrm{kJ} / \mathrm{Kg}{ }^{\circ} \mathrm{C}\right)$

$\mathrm{D}_{\mathrm{MAX}}:$ Maximum capacity of $\mathrm{HRSG}(\mathrm{kg} / \mathrm{s})$

$\mathrm{F}_{\text {MAX }}$ : Maximum steam flowrate in biomass boiler $(\mathrm{kg} / \mathrm{s})$

$\mathrm{h}_{\text {sun }}$ : Insolation hours per day (h/day)

$\mathrm{H}_{\mathrm{T}, \mathrm{P}}$ : enthalpy of steam at temperature $\mathrm{T}$ and Pressure $\mathrm{P}(\mathrm{kJ} / \mathrm{kg})$

$\mathrm{H}_{\mathrm{y}}$ : Hours per year 
$\mathrm{K}_{\mathrm{A}_{\mathrm{k}}}^{\text {biogas }}$ : $\mathrm{kg}$ of Air required in the gas turbine, $\mathrm{k}$, per $\mathrm{kg}$ of methane fed $\mathrm{K}_{\mathrm{A}_{\mathrm{q}, \mathrm{j}, \mathrm{k}}} \mathrm{kg}$ of Air required in the gas turbine, $\mathrm{k}$, per kg of syngas, $\mathrm{SY}_{\mathrm{q}, \mathrm{j}}$ $\mathrm{K}_{\mathrm{CD}}^{\text {biogas }}$ : $\mathrm{kW}$ of cooling required in the gas turbine $\mathrm{k}$ per $\mathrm{kg}$ of methane fed $\mathrm{K}_{\mathrm{CD}_{\mathrm{q}, \mathrm{j}, \mathrm{k}}}: \mathrm{kW}$ of cooling required in the gas turbine $\mathrm{k}$ per $\mathrm{kg}$ of $\operatorname{syngas} \mathrm{SY}_{\mathrm{q}, \mathrm{j}}$ $\mathrm{K}_{\mathrm{D}_{\mathrm{q}}}$ : $\mathrm{kg}$ of Flue gas, $\mathrm{D}_{\mathrm{q}}$, per $\mathrm{kg}$ of biomass processed in gasification, $\mathrm{q}$ $\mathrm{K}_{\mathrm{G}_{\mathrm{k}}}^{\text {biogas. }} \mathrm{kg}$ of exhaust gas in the gas turbine, $\mathrm{k}, \mathrm{k}$ per $\mathrm{kg}$ of methane fed $\mathrm{K}_{\mathrm{G}_{\mathrm{q}, \mathrm{j}, \mathrm{k}}}: \mathrm{kg}$ of exhaust gas in the gas turbine, $\mathrm{k}$, per kg of syngas, $\mathrm{SY}_{\mathrm{q}, \mathrm{j}}$ $\mathrm{K}_{\mathrm{O}_{\mathrm{q}} \mathrm{j}}$ : kg of oxygen required in reforming $\mathrm{q}, \mathrm{j}$ per $\mathrm{kg}$ of biomass processed $\mathrm{K}_{\mathrm{OX}_{\mathrm{q}}}: \mathrm{kg}$ of oxygen required in gasification $\mathrm{q}$ per $\mathrm{kg}$ of biomass processed $\mathrm{K}_{\mathrm{p}_{\mathrm{k}}}^{\text {biogas: }} \mathrm{kW}$ produced in the gas turbine $\mathrm{k}$ per $\mathrm{kg}$ of methane fed $\mathrm{K}_{\mathrm{P}_{\mathrm{q}, \mathrm{j}, \mathrm{k}}}: \mathrm{kW}$ produced in the gas turbine $\mathrm{k}$ per $\mathrm{kg}$ of syngas $\mathrm{SY}_{\mathrm{q}, \mathrm{j}}$ $\mathrm{K}_{\mathrm{ST}_{\mathrm{q}}}: \mathrm{kg}$ of steam required in gasification q per $\mathrm{kg}$ of biomass processed $\mathrm{K}_{\mathrm{SY}_{\mathrm{q}, \mathrm{j}}}: \mathrm{kg}$ of $\mathrm{SY}_{\mathrm{q}, \mathrm{j}}$ per $\mathrm{kg}$ of biomass processed by gasification $\mathrm{q}$ and reforming $\mathrm{j}$ $\mathrm{K}_{\mathrm{W}_{\mathrm{q} j}}: \mathrm{kg}$ of steam required in reforming q,j per kg of biomass processed $\mathrm{K}_{\text {Ammoia }}^{Z} \mathrm{~kg}$ of ammonia produced per $\mathrm{kg}$ of waste $\mathrm{z}$ fed to digestor $\mathrm{K}_{\mathrm{CH} 4}^{Z}: \mathrm{kg}$ of methane produced per $\mathrm{kg}$ of waste $\mathrm{z}$ fed to digestor $\mathrm{K}_{\mathrm{CO} 2}^{\mathrm{Z}}$ : $\mathrm{kg}$ of carbon dioxide produced per $\mathrm{kg}$ of waste $\mathrm{z}$ fed to digestor $\mathrm{K}_{\mathrm{F}}$ : constant to annualize investment cost $\mathrm{K}_{\mathrm{H}}$ : constant of cost function $\mathrm{K}_{\mathrm{W}}^{Z}$ : kg of water produced per $\mathrm{kg}$ of waste $\mathrm{z}$ fed to digestor $\mathrm{LHV}_{\mathrm{c}}$ : Lower heating value of biomass $(\mathrm{kJ} / \mathrm{kg})$ $\mathrm{LHV}_{\mathrm{CH} 4}$ : Lower Heating Value of methane $(\mathrm{kJ} / \mathrm{kg})$ $\mathrm{LHV}_{\mathrm{q}, \mathrm{j}}$ : Lower heating Value of $\mathrm{SY}_{\mathrm{q}, \mathrm{j}}(\mathrm{kJ} / \mathrm{kg})$ $\mathrm{P}_{\mathrm{m}}^{\mathrm{s}}$ : Steam pressure in unit $\mathrm{m}$ (bar) $\mathrm{P}^{\mathrm{s}}$ : Pressure of steam, s (bar) $\mathrm{R}_{\mathrm{D}_{\mathrm{q}}}^{\mathrm{n}, \mathrm{s}}: \mathrm{kg}$ of steam, $\mathrm{s}$, produced per kg of flue gas, $\mathrm{D}_{\mathrm{q}}$, in HRSG, $\mathrm{n}$. $\mathrm{R}_{\mathrm{k}, \mathrm{n}}^{\text {s,biogas: }} \mathrm{kg}$ of steam, s, generated in HRSG ,n, per $\mathrm{kg}$ of exhaust gas, $\mathrm{G}_{\mathrm{k}, \mathrm{n}}^{\text {biogas }}$. 
$\mathrm{R}_{\mathrm{q}, \mathrm{j}, \mathrm{k}}^{\mathrm{n}, \mathrm{s}}$ : $\mathrm{kg}$ of steam, $\mathrm{s}$, generated in HRSG ,n, per kg of exhaust gas, $\mathrm{G}_{\mathrm{q}, \mathrm{j}, \mathrm{k}}^{\mathrm{n}}$.

$\mathrm{SY}_{\mathrm{MAX}}$ : Maximum syngas flowrate allowed in gas turbine and syngas boiler $(\mathrm{kg} / \mathrm{s})$

$\mathrm{T}_{\mathrm{m}}^{\mathrm{s}}$ : Steam temperature in unit $\mathrm{m}\left({ }^{\circ} \mathrm{C}\right)$

TOT $_{\mathrm{q}, \mathrm{j}, \mathrm{k}}$ : Gas turbine temperature outlet

$\mathrm{T}^{\mathrm{s}}$ : Temperature of steam, $\mathrm{s}\left({ }^{\circ} \mathrm{C}\right)$

\section{Variables}

Air $_{\mathrm{q}, \mathrm{j}, \mathrm{k}}$ : Air required in the gas turbine, $\mathrm{k}$, which uses syngas, $\mathrm{SY}_{\mathrm{q}, \mathrm{j}}$, to produce power $(\mathrm{kg} / \mathrm{s})$

$\mathrm{BB}_{\mathrm{COST}}$ : Total cost of the biomass boiler (\$USD)

$\mathrm{B}_{\mathrm{c}}$ : Biomass flowrate processed in biomass boiler $(\mathrm{kg} / \mathrm{s})$

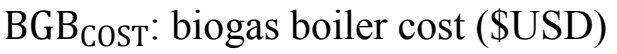

$B_{q, j}$ : Biomass processed by gasification $q$ and reforming $\mathrm{j}(\mathrm{kg} / \mathrm{s})$

$\mathrm{B}_{\mathrm{q}}$ : Biomass flowrate processed by gasification $\mathrm{q}(\mathrm{kg} / \mathrm{s})$

$\mathrm{CD}_{\text {biogas }}$ : Total cooling requirements of biogas processing $(\mathrm{kW})$

$\mathrm{CD}_{\text {biomass: }}$ Total cooling requirements of biomass processing $(\mathrm{kW})$

$\mathrm{CD}_{\mathrm{k}}^{\text {biogas }}$ : Cooling required in gas turbine, $\mathrm{k}$, which uses biogas to produce power $(\mathrm{kJ} / \mathrm{s})$

$\mathrm{CD}_{\mathrm{q}, \mathrm{j}, \mathrm{k}}$ : Cooling required in gas turbine, $\mathrm{k}$, which uses syngas, $\mathrm{SY}_{\mathrm{q}, \mathrm{j}}$, to produce power $(\mathrm{kJ} / \mathrm{s})$

$\mathrm{C}_{\mathrm{EC}}$ : Cost of unit EC (\$ USD)

Cost $_{\mathrm{COMP}_{\mathrm{q}, \mathrm{j}, \mathrm{k}}}$ : Compressor cost used to compress the syngas, $\mathrm{SY}_{\mathrm{q}, \mathrm{j}, \mathrm{k}}(\mathrm{SUSD})$

Cost $_{\mathrm{CU}_{\mathrm{n}}}:$ Cost of unit $\mathrm{CU}_{\mathrm{n}}(\mathrm{SUSD})$

$\operatorname{Cost}_{\text {DHRSG }_{\mathrm{q}}}^{\mathrm{n}}$ : Cost of HRSG, n, which uses the flue gas, $\mathrm{D}_{\mathrm{q}}^{\mathrm{n}}(\$ \mathrm{USD})$

$\operatorname{Cost}_{\mathrm{Gas}_{\mathrm{q}, \mathrm{j}}}:$ Reforming and gasification cost (\$ USD)

$\operatorname{Cost}_{\mathrm{HRSG}_{\mathrm{q}, \mathrm{j}, \mathrm{k}}}^{\mathrm{n}}$ : Cost of HRSG, $\mathrm{n}$, which uses the exhaust gas, $\mathrm{G}_{\mathrm{q}, \mathrm{j}, \mathrm{k}}^{\mathrm{n}}($ USD)

$\operatorname{Cost}_{\mathrm{SB}_{\mathrm{q}, j}}^{\text {reheat_n}}$ : Cost of steam reheating, reheat_n, in the syngas boiler (\$USD)

$\operatorname{Cost}_{\mathrm{SB}_{\mathrm{q}, \mathrm{j}}}^{\mathrm{S}}:$ Syngas boiler cost which uses syngas, $\mathrm{SY}_{\mathrm{q}, \mathrm{j}}$ to produce steam, s (\$ USD) 
$\operatorname{Cost}_{\mathrm{T}_{\mathrm{q}, \mathrm{j}, \mathrm{k}}}:$ Gas turbine cost which uses syngas, $\mathrm{SY}_{\mathrm{q}, \mathrm{j}}(\$ \mathrm{USD})$

Cost $_{\text {BiogasTurbine }_{\mathrm{k}}}$ : cost of the biogas turbine, k (\$USD)

$\operatorname{Cost}_{\mathrm{c}}^{\text {reheat_n} n:}$ : cost of steam reheating, reheat_n, in the biomass boiler (\$USD)

Cost $_{\mathrm{c}}^{\mathrm{s}}$ : Biomass boiler cost to produce steam, s (\$ USD)

$\mathrm{C}_{\text {reheat }}^{\mathrm{CSP}}$ : cost of reheating steam using molten salts (\$ USD)

$\mathrm{C}_{\text {steam }}^{\mathrm{CSP}}$ : cost of steam generation section ( $\$$ USD)

$\mathrm{D}_{\mathrm{q}}$ : Flue gas flowrate leaving combustor chamber in IG $(\mathrm{kg} / \mathrm{s})$

$\mathrm{D}_{\mathrm{q}}^{\mathrm{n}}$ : Flue gas flowrate used in HRSG, $\mathrm{n}$, to produce steam $(\mathrm{kg} / \mathrm{s})$

$\mathrm{F}_{\mathrm{D}_{\mathrm{q}}}^{\mathrm{n}, \mathrm{s}}$ : Steam, s, flowrate generated in HRSG, $\mathrm{n}$ by recovery heat from flue gas, $\mathrm{D}_{\mathrm{q}}(\mathrm{kg} / \mathrm{s})$

$\mathrm{F}_{\mathrm{SB}_{\mathrm{q}, \mathrm{j}}}^{\mathrm{S}}:$ Flowrate of steam, s, produced by a syngas boiler which uses syngas, $\mathrm{SY}_{\mathrm{q}, \mathrm{j}}(\mathrm{kg} / \mathrm{s})$

$\mathrm{F}_{\text {biomass }}^{\mathrm{S}}$ : Total of steam, $\mathrm{s}$, flowrate produced by biomass processing $(\mathrm{kg} / \mathrm{s})$

$\mathrm{F}_{\mathrm{c}}^{\mathrm{s}}$ : Flowrate of steam, s generated in biomass boiler $(\mathrm{kg} / \mathrm{s})$

$\mathrm{F}_{\max }$ : Maximum steam flowrate allowable in the steam turbine $(\mathrm{kg} / \mathrm{s})$

$\mathrm{F}_{\mathrm{m}}^{\mathrm{n}, \mathrm{g}}$ : Flowrate of exhaust gas in unit $\mathrm{m}$ of HRSG, $\mathrm{n}(\mathrm{kg} / \mathrm{s})$

$\mathrm{F}_{\mathrm{m}}^{\mathrm{n}, \mathrm{s}}$ : Steam flowrate in unit, $\mathrm{m}$, of HRSG, $\mathrm{n}(\mathrm{kg} / \mathrm{s})$

$\mathrm{F}_{\mathrm{q}, \mathrm{j}, \mathrm{k}}^{\mathrm{n}, \mathrm{s}}$ : Flowrate of steam, s, produced in HRSG, $\mathrm{n}$, by using exhaust gas, $\mathrm{G}_{\mathrm{q}, \mathrm{j}, \mathrm{k}}^{\mathrm{n}}$.

$\mathrm{F}_{\text {reheat_1 }}^{\mathrm{HP}}$ : HP steam flowrate in reheating_1 $(\mathrm{kg} / \mathrm{s})$

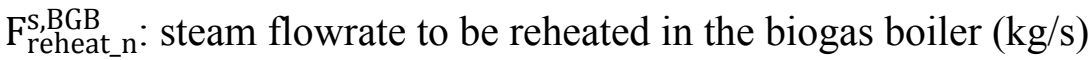

$\mathrm{F}_{\text {reheat_n } \mathrm{n}}^{\mathrm{s}, \mathrm{C}}$ : steam flowrate to be reheated in the biomass boiler $(\mathrm{kg} / \mathrm{s})$

$\mathrm{F}_{\text {reheat_n}}^{\mathrm{s}, \mathrm{j}}$ : steam flowrate to be reheated in the syngas boiler $(\mathrm{kg} / \mathrm{s})$

$\mathrm{F}_{\text {reheat_n }}^{\mathrm{S}}:$ Flowrate of steam, $\mathrm{s}$, sent to reheat $\mathrm{n}(\mathrm{kg} / \mathrm{s})$

$\mathrm{F}_{\text {reheat }}^{\text {salt }}$ Flowrate of molten salt to reheat steam $(\mathrm{kg} / \mathrm{s})$

$\mathrm{G}_{\mathrm{k}, \mathrm{n}}^{\text {biogas}}$ : Flowrate of exhaust gas, $\mathrm{G}_{\mathrm{k}, \mathrm{n}}^{\text {biogas }}$, which is used in HRSG, $\mathrm{n}(\mathrm{kg} / \mathrm{s})$

$\mathrm{G}_{\mathrm{k}}^{\text {biogas. }}$ : exhaust gas from the gas turbine, $\mathrm{k}$, which uses biogas to produce power $(\mathrm{kg} / \mathrm{s})$

$\mathrm{G}_{\mathrm{q}, \mathrm{j}, \mathrm{k}}$ : exhaust gas from the gas turbine, $\mathrm{k}$, which uses syngas, $\mathrm{SY}_{\mathrm{q}, \mathrm{j}}$, to produce power $(\mathrm{kg} / \mathrm{s})$

$\mathrm{G}_{\mathrm{q}, \mathrm{j}, \mathrm{k}}^{\mathrm{i}, \mathrm{n}}$ : Exhaust gas flowrate from turbine, $\mathrm{q}, \mathrm{j}, \mathrm{k}$, in HRSG, $\mathrm{n}(\mathrm{kg} / \mathrm{s})$

$\mathrm{G}_{\mathrm{q}, \mathrm{j}, \mathrm{k}}^{\mathrm{n}}$ : Flowrate of exhaust gas, $\mathrm{G}_{\mathrm{q}, \mathrm{j}, \mathrm{k}}$, which is used in HRSG, $\mathrm{n}(\mathrm{kg} / \mathrm{s})$ 
OpCost $_{\mathrm{Gas}_{\mathrm{q}, \mathrm{j}}}$ : operation cost of gasification and reforming ( \$USD/S)

$O X_{\mathrm{q}}$ : Oxygen required in gasification, $\mathrm{q},(\mathrm{kg} / \mathrm{s})$

Oxygen $_{\mathrm{q}, \mathrm{j}}$ : Oxygen required in reforming, $\mathrm{j}$, to process the syngas obtained from gasification, $\mathrm{q},(\mathrm{kg} / \mathrm{s})$

$\mathrm{Pco}_{\mathrm{q}, \mathrm{j}, \mathrm{k}}$ : Power required to compress air and syngas, $\mathrm{SY}_{\mathrm{q}, \mathrm{j}}(\mathrm{kW})$

$\mathrm{P}_{\mathrm{k}}^{\text {biogas: }}$ Power produced in the gas turbine, $\mathrm{k}$, by using biogas $(\mathrm{kW})$

$\mathrm{P}_{\mathrm{q}, \mathrm{j}, \mathrm{k}}$ : Power produced in the gas turbine, $\mathrm{k}$, by using syngas, $\mathrm{SY}_{\mathrm{q}, \mathrm{j}}(\mathrm{kW})$

$\mathrm{QSB}_{\mathrm{q}, j}^{\mathrm{S}}$ : Heat required to produce steam, s, in a syngas boiler which uses syngas, $\mathrm{SY}_{\mathrm{q}, \mathrm{j}}(\mathrm{kJ} / \mathrm{s})$

$\mathrm{Q}_{\mathrm{TSB}_{\mathrm{q}, \mathrm{j}}}$ : Total heat of the syngas boiler which uses syngas, $\mathrm{SY}_{\mathrm{q}, \mathrm{j}}(\mathrm{kJ} / \mathrm{s})$

$\mathrm{Q}_{\mathrm{BGB}}^{\mathrm{S}}$ : Heat required to produce steam, $\mathrm{s}$, in biogas boiler $(\mathrm{kJ} / \mathrm{s})$

$\mathrm{Q}_{\mathrm{c}}^{\mathrm{s}}$ : Heat required to produce steam, $\mathrm{s}$, in biomass boiler $(\mathrm{kJ} / \mathrm{s})$

$\mathrm{Q}_{\mathrm{E}}$ : Heat in unit $\mathrm{E}(\mathrm{kJ} / \mathrm{s})$

$\mathrm{Q}_{\mathrm{m}}^{\mathrm{n}, \mathrm{s}}$ : Steam heat in unit $\mathrm{m}$ of HRSG, $\mathrm{n}(\mathrm{kJ} / \mathrm{s})$

$\mathrm{Q}_{\text {reheat_n}}^{\mathrm{BGB}}$ : Heat required to carry out the steam reheating, reheat_n, in the biogas boiler $(\mathrm{kJ} / \mathrm{s})$

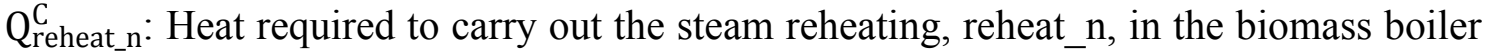
$(\mathrm{kJ} / \mathrm{s})$

$\mathrm{Q}_{\text {reheat_n}}^{\mathrm{q}, \mathrm{j}}$ : Heat required to carry out the steam reheating, reheat_n, in the syngas boiler $(\mathrm{kJ} / \mathrm{s})$

$\mathrm{Q}_{\text {reheat }}^{\mathrm{BGB}}$ : Heat required to carry out the steam reheating in the biogas boiler $(\mathrm{kJ} / \mathrm{s})$

$\mathrm{Q}_{\text {reheat: }}^{\mathrm{C}}$ Total heat required to carry out the steam reheating in the biomass boiler $(\mathrm{kJ} / \mathrm{s})$

$\mathrm{Q}_{\text {reheat }}^{\mathrm{q}, \mathrm{j}}$ : Total heat required to carry out the steam reheating in the syngas boiler $(\mathrm{kJ} / \mathrm{s})$

$\mathrm{Q}_{\mathrm{steam}}^{\mathrm{CSP}}$ : Heat required to produce steam $(\mathrm{kJ} / \mathrm{s})$

$\mathrm{Q}_{\mathrm{TBGB}}$ : Total heat required to produce steam in biogas boiler $(\mathrm{kJ} / \mathrm{s})$

$\mathrm{Q}_{\mathrm{Tc}}$ : Total heat in biomass boiler $(\mathrm{kJ} / \mathrm{s})$

$\mathrm{Q}_{\text {unit1 }}$ : Heat in unit1 $(\mathrm{kJ} / \mathrm{s})$

$\mathrm{SB}_{\mathrm{COST}}$ : Total cost of the syngas boiler (\$USD)

$\mathrm{ST}_{\mathrm{q}}$ : : steam required in gasification, $\mathrm{q},(\mathrm{kg} / \mathrm{s})$

$\mathrm{SY}_{\mathrm{q}, \mathrm{j}, \mathrm{k}}$ : Syngas flowrate $\mathrm{SY}_{\mathrm{q}, \mathrm{j}}$ sent to gas turbine $\mathrm{k}(\mathrm{kg} / \mathrm{s})$ 
$\mathrm{SY}_{\mathrm{q}, \mathrm{j}, \mathrm{sb}}$ : Syngas flowrate $\mathrm{SY}_{\mathrm{q}, \mathrm{j}}$ sent to syngas boiler $(\mathrm{kg} / \mathrm{s})$

$\mathrm{SY}_{\mathrm{q}, \mathrm{j}}$ : Syngas flowrate generated by gasification $\mathrm{q}$ and reforming $\mathrm{j}(\mathrm{kg} / \mathrm{s})$

TAC $^{\mathrm{n}}$ : Total annualized cost of HRSG, $\mathrm{n}(\$ \mathrm{USD} /$ year)

$\mathrm{T}_{\mathrm{m}}^{\mathrm{n}, \mathrm{g}}$ : Temperature of exhaust gas in unit $\mathrm{m}$ of HRSG, $\mathrm{n}\left({ }^{\circ} \mathrm{C}\right)$

Waste $_{\mathrm{z}}$ : Flowrate of was, $\mathrm{z}$, used in to produce biogas $(\mathrm{kg} / \mathrm{s})$

Water $_{\mathrm{q}, j}$ : steam required in reforming, $\mathrm{j}$, to process the syngas obtained from gasification, $\mathrm{q},(\mathrm{kg} / \mathrm{s})$

WATER $_{\mathrm{z}}$ : water flowrate produced by waste $\mathrm{z}(\mathrm{kg} / \mathrm{s})$

Cost $_{\mathrm{CSP}}$ Total cost of CSP plat (\$USD)

B: Biomass flowrate to processed $(\mathrm{kg} / \mathrm{s})$

Cost_BIOMASS: Total cost of biomass processing (\$USD)

Opcost: Total Operation cost of biomass processing (\$ USD/s)

OpCSP: Annualized operating cost (\$ USD/year)

Power $_{\text {biomass: }}$ Total power produced by biomass processing $(\mathrm{kW})$

\section{Binary variables}

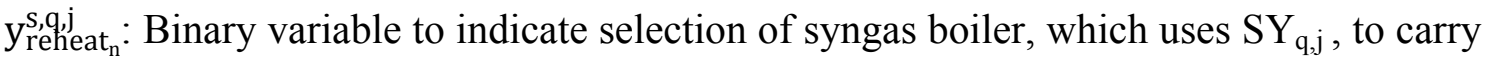
out steam reheating, reheat_n

$\mathrm{y}_{\mathrm{c}}$ : Binary variable to select biomass boiler

$\mathrm{y}_{\mathrm{c}}^{\mathrm{s}}$ : Binary variable to indicate the production steam, $\mathrm{s}$ in biomass boiler

$\mathrm{y}_{\mathrm{Dq}}^{\mathrm{n}}$ : Binary variable to select $\mathrm{HRSG}, \mathrm{n}$ that uses flue gas, $\mathrm{D}_{\mathrm{q}}^{\mathrm{n}}$, to produce steam

$\mathrm{y}_{\mathrm{q}, \mathrm{j}, \mathrm{k}}$ : Binary variable to select gas turbine, $\mathrm{k}$, to which syngas, $\mathrm{SY}_{\mathrm{q}, \mathrm{j}}$, is sent

$\mathrm{y}_{\mathrm{q}, \mathrm{j}, \mathrm{k}}^{\mathrm{n}}$ : Binary variable to select HRSG, $\mathrm{n}$, which uses exhaust gas, $\mathrm{G}_{\mathrm{q}, \mathrm{j}, \mathrm{k}}^{\mathrm{n}}$ to produce steam

$\mathrm{y}_{\mathrm{q}, \mathrm{j}, \mathrm{sb}}$ : Binary variable to select syngas boiler

$\mathrm{y}_{\mathrm{q}, \mathrm{j}, \mathrm{sb}}^{\mathrm{s}}$ : Binary variable to select production of steam, $\mathrm{s}$ in a syngas boiler which uses syngas, $\mathrm{SY}_{\mathrm{q}, \mathrm{j}}$

$\mathrm{y}_{\mathrm{q}, \mathrm{j}}$ : Binary variable to select gasification $\mathrm{q}$ and reforming $\mathrm{j}$

$\mathrm{y}_{\mathrm{q}}$ : Binary variabale to select gasification $\mathrm{q}$

$\mathrm{y}_{\text {reheat_n }}^{\mathrm{S}, \mathrm{BGB}}$ : Binary variable to indicate selection of biomass boiler to carry out steam reheating, reheat_n 


\section{References}

(1) Phillips, S., Aden, A., Jechura, J., Dayton, D., \& Eggeman, T. (2007). Thermochemical ethanol via indirect gasification and mixed alcohol synthesis of lignocellulosic biomass (No. NREL/TP-510-41168). National Renewable Energy Lab.(NREL), Golden, CO (United States). Accessed in March 2018: http://neotericsint.com/pubs/Mixed\%20Alcohols.pdf.

(2) Dutta, A., \& Phillips, S. D. (2009). Thermochemical ethanol via direct gasification and mixed alcohol synthesis of lignocellulosic biomass (No. NREL/TP-510-45913). National Renewable Energy Lab.(NREL), Golden, CO (United States). Accessed in March 2018 : https://www.nrel.gov/docs/fy09osti/45913.pdf.

(3) Spath, P., Aden, A., Eggeman, T., Ringer, M., Wallace, B., \& Jechura, J. (2005). Biomass to hydrogen production detailed design and economics utilizing the Battelle Columbus laboratory indirectly-heated gasifier (No. NREL/TP-510-37408). National Renewable Energy Lab., Golden, CO (US).

(4) Ulrich, G. D., \& Vasudevan, P. T. (2006). How to estimate utility costs. Chem. Eng, 113(4), 66-69.

(5) Almena, A., \& Martín, M. (2015). Technoeconomic analysis of the production of epichlorohydrin from glycerol. Ind. Eng. Chem. Res., 55(12), 3226-3238.

(6) National Renewable Energy Laboratory. (NREL). National solar radiation database 1998-2014. 2014. https://rredc.nrel.gov/solar/old data/nsrdb/.

(7) Centro Nacional de Control de Energía. (CENACE). Estimación de la Demanda Real del

2018.

https://www.cenace.gob.mx/SIM/VISTA/REPORTES/DemandaRealSist.aspx (Accessed in November 2018).

(8) Inventario Nacional de Energías Limpias (INEL). 2018. https://dgel.energia.gob.mx/inel/mapa.html?lang=es.

(9) Secretaria del medio ambiente y recursos naturales. (Semarnat). Informe de la situación del medio ambiente en México, 380. 2015. http://apps1.semarnat.gob.mx/dgeia/informe15/tema/pdf/Cap7 Residuos.pdf.

(10) Servicio de Información Agroalimentaria y Pesquera. (SIAP). 2017. http://infosiap.siap.gob.mx 